\title{
Relative abundance and status of water birds in Taungthaman lake, Mandalay, Myanmar
}

\begin{abstract}
Relative abundance and status of bird species were studied in Taungthaman Lake, during January 2016 to December 2016. Line transect count method was carried out. A total of 27 species, distributed under 20 genera, representing 12 families and 5 orders were observed. The largest number of species was recorded in November and the lowest in August and the largest number of individuals was found in January and the lowest in July. Relative abundance indicated that seven species were found as very common (vC), only one species as common (C) and 18 species as uncommon (uC). According to the International Union for the Conservation of Nature (2015), 26 species were in the Least Concern category, one species Anhinga melanogaster was in the Near Threatened. Thus, the Taungthaman Lake supports a sound avifaunal diversity. Its proper management will not only improve the situation for its resident species, but will also attract more migratory and vagrant species in the future.
\end{abstract}

Keywords: aquatic birds, occurrence, population status, geographic location, Taungthaman lake

\author{
Special Issue - 2018
}

\section{Nyunt Lwin, 'Thandar Saw, ${ }^{2}$ Thant Zin'}

'Department of Zoology, University of Mandalay, Myanmar

${ }^{2}$ Department of Zoology, Yadanabon University, Myanmar

Correspondence: Nyunt Lwin, Lecturer, Department of Zoology, University of Mandalay, Myanmar, Email:nyuntlwin7@gmail.com

Received: May 02, 2018 | Published: August 01, 2018

\section{Introduction}

Birds are sensitive indicators of pollutions in both terrestrial and aquatic ecosystems. ${ }^{1}$ They are among the best monitors of environmental changes. $^{2}$ In ecology, they are of tremendous importance because of their key roles as pollinators and agents of seed dispersal. ${ }^{3}$ Habitats also change seasonally and over a period of years as successional change proceeds in a plant community. The geographic location of different habitats shifts as the climate changes. ${ }^{4}$

Birds form a class of animals that includes over 10000 species worldwide. ${ }^{5}$ Of these, a total of 1327 species are known to occur in South-East Asia. ${ }^{6}$ In Myanmar, a total of 1114 species of which six are endemic, two have been introduced by humans and ten are rare of accidental. One species listed is extirpated. Of these 51 species are globally threatened. Eight of these species are critically endangered, twelve endangered and twenty-six are vulnerable species.?

Waterbirds depend on wetlands for a variety of activities which include feeding, breeding, nesting and moulting. The highest number of waterbirds is often found in wetlands which have the greatest diversity of plant species and vegetation types, or where there is permanent water.

The wetlands of Myanmar is directly or indirectly associated with river systems, a total of 99 wetland sites including swamp land were identified. The most of these wetlands are located alongside the Ayeyawady/Chindwin River and 85 sites and a few wetlands are found in the Thanlwin river basin (6 sites) and in the Sittaung river basin ( 5 sites). The Rakhine coastal region also hosts another 3 wetland sites. These wetlands are not only important for fresh water biodiversity but also the home of globally threatened bird species (National Biodiversity Strategy and Action Plan Myanmar, 2001). ${ }^{9}$

Taungthaman Lake is a natural flood plain with the main inflow of water from the Ayeyarwady River in the rainy season. This natural flood-plain is transformed into a permanent lake by the construction of water control gates for fishery. Nowadays, water is not controlled and fishery industry is not done in the lake. More people come to the lake than initially and habitat is not good for birds. Bird species have decreased in the lake especially waterbirds. Therefore, the present study aimed to investigate the avifauna in Taungthaman Lake especially on species composition, occurrence and abundance.

\section{Materials and methods}

\section{Study area}

Taungthaman Lake is situated in Amarapura Township of Mandalay Region on the eastern bank of the Ayeyawady River. It lies between $21^{\circ}$ $53^{\prime} \mathrm{N}$ to $21^{\circ} 54^{\prime} \mathrm{N}$ latitude and $96^{\circ} 03^{\prime} \mathrm{E}$ to $96^{\circ} 05^{\prime} \mathrm{E}$ longitude (Figure 1). It is situated about seven miles $(11 \mathrm{~km})$ away from the southwest of Mandalay. Its depth is 8-15feet (2.4-4.57meters) with the area of about 1000acres (404.7hectares).

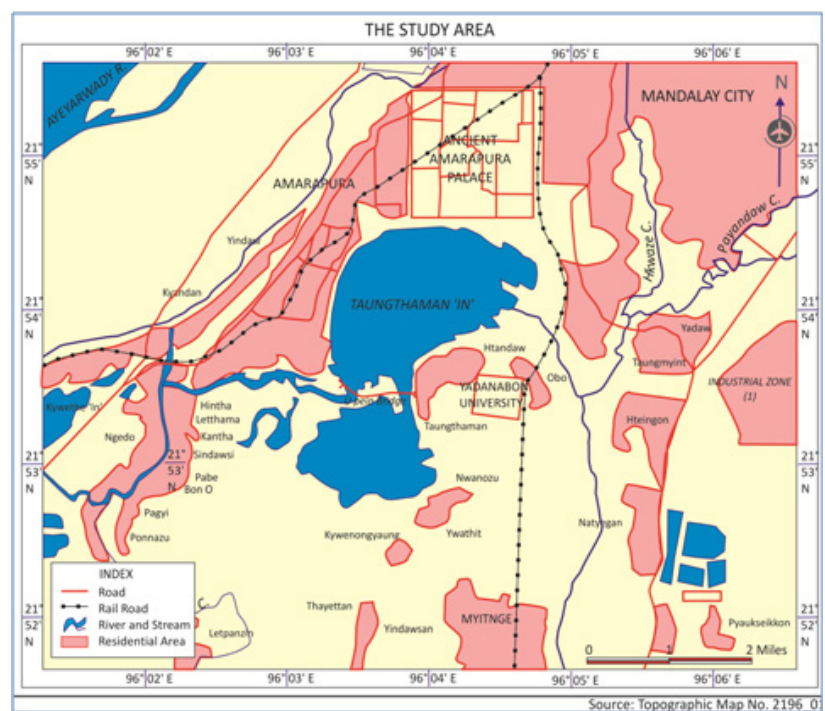

Figure I Location map of study area, Taungthaman Lake. 


\section{Data collection}

The study was carried out between January 2016 and December 2016. Line transect method was used, as the study area was of open type.$^{10}$ Birds were counted by boat and walk in the edge of lake and its environs. The field surveys were conducted in the morning (between 6:30-10:30am) about 3:00hours after sunrise and in the evening (between 3:30 - 5:30) when the activities of birds were prominent Birds were collected one time in per month and observed using the Seeker Coated Optics binocular (10×50 DPSI), and photographs were taken with a Canon Ultrasonic camera (65 X Optimal Zoom, 16.1 Mega Pixels, Japan) for further identification. The International Union for the Conservation of Nature (IUCN, 2015) ${ }^{6}$ status was also used to compare the local status with the global status. Birds were identified by Symithes ${ }^{11} \&$ Robson. ${ }^{12}$ Birds' nomenclature was based on Robson ${ }^{12}$ and Avibase - Bird Checklists of the World, Myanmar. ${ }^{13}$

\section{Analysis of data}

The recorded data was analyzed as follow after Bisht et al., 2004: Relative abundance $=\begin{gathered}\text { No. of individuals of a species } \\ \text { Total no. of individuals of all species }\end{gathered}$
The average relative abundance was categorized adopted by Bisht et al. (2004)

$\mathrm{uC}=$ uncommon having relative abundance of less than 0.0100

$\mathrm{C}=$ common having relative abundance of 0.0100 and above but less than 0.0500

$\mathrm{vC}=$ very common having relative abundance of 0.0500 and above.

\section{Results and discussion}

\section{Results}

The study revealed that a total of 27 species (25,375 individuals) in 20 genera of birds belonging to 12 families and five orders were present in the study area (Figure 2, Table 1). The analysis of data on residential status revealed that out of 27 species, nine were resident (R) whereas the remaining 18 species showed seasonal only. Among these, one was as resident, other one was local movement (R/LM) as rare $(\mathrm{Ra})$ and passage migration (16 species) were identified as winter visitor (WV) (Table 2). Of these, Anhinga melanogaster was placed in the near threatened (NT) and others 26 species were least concern (LC) as in IUCN Red-list 2015 (Table 2).

Table I List of recorded bird species in Taungthaman Lake during January 2016 to December 2016

\begin{tabular}{|c|c|c|c|c|c|c|c|}
\hline No. & Order & No. & Family & No. & Species & Common name & Local name \\
\hline \multirow{2}{*}{ I } & \multirow{2}{*}{ Anseriformes } & \multirow{2}{*}{1} & \multirow{2}{*}{ Anatidae } & I & Tadorna ferruginea & Ruddy Shelduck & hin-tha \\
\hline & & & & 2 & Ana strepera & Gadwall & - \\
\hline 2 & Phoenicopteriformes & 2 & Podicipedidae & 3 & Tachybaptus ruficollis & Little Grebe & ta-si-mhoke \\
\hline \multirow{2}{*}{3} & \multirow{2}{*}{ Gruiformes } & \multirow{2}{*}{3} & \multirow{2}{*}{ Rallidae } & 4 & Gallinula chloropus & Common moorhen & ye-kyet-ma \\
\hline & & & & 5 & Porzana cinerea & White-browed Crake & ye-kyet \\
\hline \multirow{9}{*}{4} & \multirow{10}{*}{ Pelecaniformes } & \multirow{6}{*}{4} & \multirow{6}{*}{ Ardeidae } & 6 & Ardea cinerea & Grey Heron & nga-hit-mwe \\
\hline & & & & 7 & Ardeola bacchus & Chinese Pond Heron & byaing-auk \\
\hline & & & & 8 & Andeola grayi & Indian Pond Heron & byaing-auk \\
\hline & & & & 9 & Camerodius albus & Great Egret & byaing-ngan \\
\hline & & & & 10 & Mesophoyx intermedia & Intermediate Egret & tharrawaddy-byaing \\
\hline & & & & II & Egretta garzetta & Little Egret & byaing \\
\hline & & \multirow{2}{*}{5} & \multirow{2}{*}{ Threskiornithidae } & 12 & Plegadis falcinellus & Glossy lbis & gaut \\
\hline & & & & 13 & Pseudibis papillosa & Red-naped Ibis & kha-yu-soke \\
\hline & & 6 & Phalacrocoracidae & 14 & Phalacrocorax niger & Little Cormorant & din-gyi \\
\hline \multirow{13}{*}{5} & & 7 & Anhingidae & 15 & Anhinga melanogaster & Darter & u-pan \\
\hline & \multirow{12}{*}{ Charadriiformes } & 8 & Recurvirostridae & 16 & Himantopus himantopus & Black-winged Stilt & daung-lan-chi-dauk \\
\hline & & \multirow{5}{*}{9} & \multirow{5}{*}{ Charadriidae } & 17 & Chardrius blaticula & Common-ring Plover & hnet-phyone-tee \\
\hline & & & & 18 & Chardrius dubius & Little-ring Plover & ta laing lay \\
\hline & & & & 19 & Chardrius mongolus & Lesser Sand Plover & - \\
\hline & & & & 20 & Chardrius leschenaultii & Greater Sand Plover & ye-hnyant \\
\hline & & & & 21 & Chardrius veredus & Oriental Plover & - \\
\hline & & 10 & Jacanidae & 22 & Metopidius indicus & Bronze-winged Jacana & kya-bet-nin \\
\hline & & \multirow{4}{*}{ II } & \multirow{4}{*}{ Scolopacidae } & 23 & Tringa ochropus & Green Sandpipper & - \\
\hline & & & & 24 & Tringa glareola & Wood Sandpiper & - \\
\hline & & & & 25 & Actitis hypoleucos & Common Sandpiper & - \\
\hline & & & & 26 & Tringa stagnatilis & Marsh Sandpiper & - \\
\hline & & 12 & Laridae & 27 & Larus brunnicephalus & Brown-headed Gull & zin-yaw \\
\hline
\end{tabular}


Table 2 Monthly occurrence, abundance and status of waterbirds in Taungthaman Lake during January 2016 to December 2016

\begin{tabular}{|c|c|c|c|c|c|c|c|c|c|c|c|c|c|c|c|c|c|}
\hline Species & Jan & Feb & Mar & Apr & May & Jun & Jul & Aug & Sep & Oct & Nov & Dec & Total & $\begin{array}{l}\text { Abundance } \\
\text { (\%) }\end{array}$ & $\begin{array}{l}\text { Relative } \\
\text { abundance }\end{array}$ & $\begin{array}{l}\text { IUCN } \\
\text { status }\end{array}$ & $\begin{array}{l}\text { Residential } \\
\text { status }\end{array}$ \\
\hline $\begin{array}{l}\text { Tadorna } \\
\text { ferruginea }\end{array}$ & 4 & 0 & 0 & 0 & 0 & 0 & 0 & 0 & 22 & 80 & 160 & 295 & 561 & 2.211 & Uc & LC & $W V$ \\
\hline Ana strepera & 13 & 0 & 0 & 0 & 0 & 0 & 0 & 0 & 0 & 11 & 12 & 4 & 40 & 0.158 & Uc & LC & $w V$ \\
\hline $\begin{array}{l}\text { Tachybaptus } \\
\text { ruficollis }\end{array}$ & 16 & 12 & 0 & & 0 & 0 & 0 & 0 & 0 & 8 & 19 & 3 & 58 & 0.229 & Uc & LC & $W V$ \\
\hline $\begin{array}{l}\text { Gallinula } \\
\text { chloropus }\end{array}$ & 14 & 14 & 22 & 16 & 12 & 4 & 0 & 0 & 0 & 4 & 3 & 8 & 97 & 0.382 & C & LC & $\mathrm{R}$ \\
\hline $\begin{array}{l}\text { Porzana } \\
\text { cinerea }\end{array}$ & 0 & 0 & 0 & 0 & 1 & 0 & 0 & 0 & 0 & 0 & 0 & 0 & I & 0.004 & $\mathrm{Ra}$ & LC & $\mathrm{R} / \mathrm{LM}$ \\
\hline Ardea cinerea & 200 & 120 & 10 & 0 & 0 & 0 & 0 & 0 & 0 & 33 & 35 & 28 & 426 & 1.679 & Uc & LC & $R$ \\
\hline $\begin{array}{l}\text { Ardeola } \\
\text { bacchus }\end{array}$ & 33 & 68 & 48 & 33 & 22 & 16 & 12 & 18 & 44 & 60 & 78 & 78 & 510 & 2.01 & Vc & LC & $\mathrm{R}$ \\
\hline Andeola grayi & 22 & 29 & 22 & 16 & 16 & 8 & 6 & 12 & 23 & 4 & 8 & 8 & 174 & 0.686 & Vc & LC & $\mathrm{R}$ \\
\hline $\begin{array}{l}\text { Camerodius } \\
\text { albus }\end{array}$ & 500 & 200 & 180 & 82 & 75 & 66 & 18 & 180 & 224 & 212 & 218 & 260 & 2215 & 8.729 & $V_{c}$ & LC & $\mathrm{R}$ \\
\hline $\begin{array}{l}\text { Mesophoyx } \\
\text { intermedia }\end{array}$ & 900 & 824 & $44 I$ & 260 & 98 & 98 & 49 & 120 & 250 & 401 & 429 & 650 & 4520 & 17.81 & $V_{c}$ & LC & $\mathrm{R}$ \\
\hline $\begin{array}{l}\text { Egretta } \\
\text { garzetta }\end{array}$ & 1300 & 960 & 845 & 330 & 420 & 401 & 168 & 380 & 450 & 914 & 680 & 448 & 7296 & 28.75 & $V_{c}$ & LC & $\mathrm{R}$ \\
\hline $\begin{array}{l}\text { Plegadis } \\
\text { falcinellus }\end{array}$ & 240 & 220 & 4 & 0 & 0 & 0 & 0 & 0 & 280 & 304 & 362 & 220 & 1630 & 6.424 & Uc & LC & $W V$ \\
\hline $\begin{array}{l}\text { Pseudibis } \\
\text { papillosa }\end{array}$ & 18 & 10 & 0 & 0 & 0 & 0 & 0 & 0 & 0 & 25 & 24 & 24 & 101 & 0.398 & Uc & LC & $w V$ \\
\hline $\begin{array}{l}\text { Phalacrocorax } \\
\text { niger }\end{array}$ & 100 & 50 & 240 & 33 & 16 & 18 & 13 & 0 & 42 & 80 & 68 & 90 & 750 & 2.956 & $V_{c}$ & LC & $\mathrm{R}$ \\
\hline $\begin{array}{l}\text { Anhinga } \\
\text { melanogaster }\end{array}$ & 88 & 78 & 48 & 18 & 12 & 16 & 8 & 20 & 0 & 28 & 54 & 56 & 426 & 1.679 & $V_{c}$ & NT & $\mathrm{R}$ \\
\hline $\begin{array}{l}\text { Himantopus } \\
\text { himantopus }\end{array}$ & 1080 & 680 & 22 & 0 & 0 & 0 & 0 & 0 & 0 & 402 & 9 & 724 & 2917 & 11.5 & Uc & LC & $W V$ \\
\hline $\begin{array}{l}\text { Chardrius } \\
\text { blaticula }\end{array}$ & 22 & 14 & 8 & 0 & 0 & 0 & 0 & 0 & 0 & 12 & 16 & 18 & 90 & 0.355 & Uc & LC & $w V$ \\
\hline $\begin{array}{l}\text { Chardrius } \\
\text { dubius }\end{array}$ & 80 & 30 & 22 & 0 & 0 & 0 & 0 & 0 & 0 & 8 & 22 & 11 & 173 & 0.682 & Uc & LC & $W V$ \\
\hline $\begin{array}{l}\text { Chardrius } \\
\text { mongolus }\end{array}$ & 14 & 12 & 0 & 0 & 0 & 0 & 0 & 0 & 0 & 2 & 12 & 10 & 50 & 0.197 & Uc & LC & $w V$ \\
\hline $\begin{array}{l}\text { Chardrius } \\
\text { leschenaultii }\end{array}$ & 11 & 10 & 0 & 0 & 0 & 0 & 0 & 0 & 0 & 1 & 3 & 9 & 34 & 0.134 & Uc & LC & $w V$ \\
\hline $\begin{array}{l}\text { Chardrius } \\
\text { veredus }\end{array}$ & 9 & 6 & 8 & 0 & 0 & 0 & 0 & 0 & 0 & 6 & 8 & 4 & 41 & 0.162 & Uc & LC & $w V$ \\
\hline $\begin{array}{l}\text { Metopidius } \\
\text { indicus }\end{array}$ & 22 & 24 & 38 & 0 & 0 & 0 & 0 & 0 & 0 & 4 & 9 & 13 & 110 & 0.433 & Uc & LC & $w V$ \\
\hline $\begin{array}{l}\text { Tringa } \\
\text { ochropus }\end{array}$ & 7 & 7 & 0 & 0 & 0 & 0 & 0 & 0 & 0 & 3 & 11 & 6 & 34 & 0.134 & Uc & LC & $W V$ \\
\hline $\begin{array}{l}\text { Tringa } \\
\text { glareola }\end{array}$ & 4 & 5 & 0 & 0 & 0 & 0 & 0 & 0 & 0 & 8 & 2 & 8 & 27 & 0.106 & Uc & LC & $W V$ \\
\hline $\begin{array}{l}\text { Actitis } \\
\text { hypoleucos }\end{array}$ & 3 & 2 & 0 & 0 & 0 & 0 & 0 & 0 & 0 & 8 & 8 & 12 & 33 & 0.13 & Uc & LC & $w V$ \\
\hline $\begin{array}{l}\text { Tringa } \\
\text { stagnatilis }\end{array}$ & 5 & 0 & 0 & 0 & 0 & 0 & 0 & 0 & 0 & 6 & 3 & 8 & 22 & 0.087 & Uc & LC & $W V$ \\
\hline Larus canus & 1100 & 760 & 0 & 0 & 0 & 0 & 0 & 0 & 0 & 0 & 339 & 840 & 3039 & 11.98 & Uc & LC & $w V$ \\
\hline $\begin{array}{l}\text { Total no. of } \\
\text { individuals }\end{array}$ & 5805 & 4135 & 1958 & 788 & 672 & 627 & 274 & 730 & 1335 & 2624 & 2592 & 3835 & 25375 & & & & \\
\hline $\begin{array}{l}\text { Total no. of } \\
\text { species }\end{array}$ & 26 & 23 & 18 & 8 & 12 & 8 & 8 & 7 & 8 & 15 & 26 & 26 & 27 & & & & \\
\hline
\end{tabular}

$\mathrm{uC}=$ Uncommon, $\mathrm{C}=$ Common, $\mathrm{vC}=$ Very common, $\mathrm{WV}=$ Winter Visitor, $\mathrm{R}=$ Resident, $\mathrm{R} / \mathrm{LM}=$ Resident and local movement, $\mathrm{LC}=\mathrm{Least} \mathrm{Concern}, \mathrm{NT}=\mathrm{Near}$ Threatened 


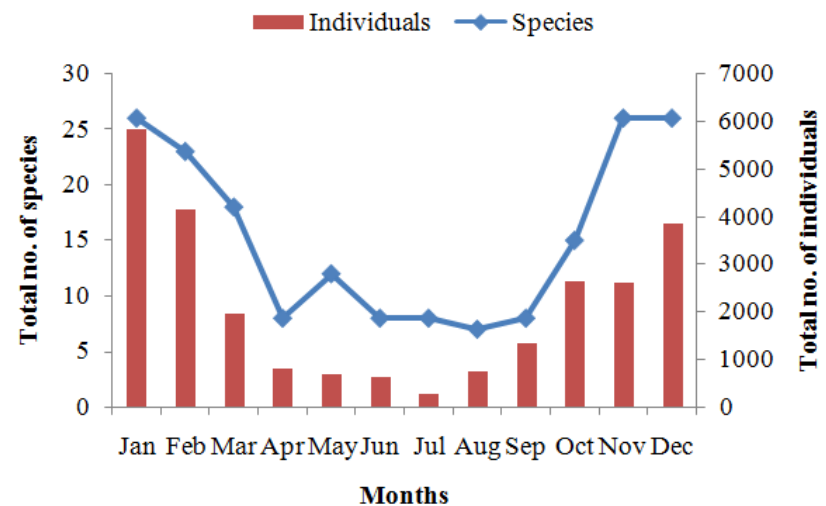

Figure 2 Relative monthly recorded bird species and individuals in Tanugthaman Lake.

\section{Discussion}

Taungthaman Lake is a natural flood plain flooded by the inflow of Ayeyarwady River in the rainy season. The water from the lake flowed down in the hot season. The vegetation cover and conditions attract the most birds because of their food, shelters and breeding sites. During the study period, 27 species of waterbirds were recorded. Waterbirds species depend on wetlands for feeding and breeding. Most of the waterbirds require flooding of wetlands for breeding (Scott). ${ }^{14}$ In the present area, the most coverage is microhabitat was found with bushes and grasses. The dominated abundant of waterbird species were observed in January, November and December 2016 (26 species each), the lowest was found in August 2016 (7 species). The highest individual number (5805) was observed in January, 2016 and the lowest individual number (274) was found in July, 2016. It is assumed that habitat is more suitable for bird species in November because of the cultivated vegetable is growth and the water condition is shallow with water insects, algae and zooplankton and also migrate birds were abundantly found. In August, the water full in the lake and the habitat coverage change and the value of habitat low for the birds. Due to the rainy season, most birds are hidden in suitable habitat their shelter.

On the other hand, the highest number of species in different orders was found in Charadriiformes (10 species). It is due to the most recorded birds were migrate birds (winter visitor). Of these Himantopus himantopus, Black-winged Stilt, and Larus brunnicephalus, Brownheaded Gull was more abundantly found in this study area. The lowest species was found in order Phoenicopteriformes and Gruiformes (one species each). Porzana cinerea was observed only one time in all study times.

Regarding the status, according to IUCN ${ }^{6}$ in 27 species, Anhinga melanogaster is near threaten (NT) and Porzana cinerea is rare (Ra) were observed.

In Myanmar, a total number of 1078 bird species include. Five species are endemic, 55 species are globally threatened species and two are introduced species. ${ }^{13}$ In this recorded of 27 species, 9 species are resident whereas the remaining 18 species, of these 17 are winter visitor and one species is seasonal resident/ local movement. According to observed, Anhinga melanogaster is near threatened (NT) and others 26 species were least concern (LC).

The formerly widespread White-shouldered Ibis Pseudibis davisoni has not been seen in Myanmar since the 1940s. ${ }^{15}$ The Pink- headed Duck Rhodonessa caryophyllacea was the focus of several intensive searches in the early 2000s, which did not produce any reliable records despite visiting most of the remaining superficially suitable habitats. ${ }^{16}$ Similarly, that the two species White-shouldered Ibis and The Pink-headed Duck were not seen in this study area Taungthaman Lake.

Lebbin ${ }^{17}$ stated that the physical environments inhabited by living organisms, are fundamental to their survival.

In the case of birds, habitat provides cover from predators, breeding, wintering and migration stopover sites, and places to forage and roost. All of the habitats used by a bird play role in its survival and the loss or degradation of any one of them can potentially have a population level impact. In that habitat loss is the greatest threat to birds. It is concluded that the abundance of bird species depends on food availability and suitable habitat.

\section{Conclusion}

The study area, Taungthaman Lake is mainly microhabitat types with the aquatic insects, algae and others content of water substances. Most villagers are chiefly dependent on agriculture for their livelihood. Therefore, a variety of habitats and environments of this condition attract and support a variety of bird species. Continuous monitoring of avian fauna is an excellent means of monitoring the lake health, and it will also help to this area as a sustainable improvement of the habitat. In the future, with the improvement of the habitat coverage, proper management programs and strategies in the lake and its environs will not only increase the number of resident bird species but will also attract migratory and vagrant species.

\section{Acknowledgements}

The authors to express their gratitude to the Department of Higher Education, Minister of Education for financial support in this research project and also thank to Dr Thidar Win, Rector, University of Mandalay for her permission to do this project.

\section{Conflict of interest}

The author declares no conflict of interest.

\section{References}

1. Gregory RD, Vorisek P, Van Strien A, et al. The generation and use of bird population indicators in Europe. Bird Conserv. 2008;18:223-224.

2. Harisha MN and Hosetti BB. Diversity and distribution of avifauna of Lakkavalli range forest, Bhadra Wildlife Sanctuary,Western Ghat, India. Ecoprint. 2009;16:21-27.

3. Bibi F, Ali Z. Measurement of diversity indices of avian communities at Taunsa Barrage Wildlife Sanctuary, Pakistan. Journal of Animal and Plant Sciences. 2013;23(2):469-474.

4. Gill FB. Ornithology. New York: W.H. Freeman and Company; 2001.

5. Clements J. Clements checklist of birds of the world. New York: Cornell University Press; 2007.

6. Robson. A field guide to the birds of South-East Asia. London: Bloombury Publishers (UK) Ltd; 2015.

7. IUCN. The IUCN Red List of Threatened Species. Version 4. 2015.

8. Balla S. Wetlands of the Swan Coastal Plain, Volume 1. Their nature and management. Water Authority of Western Australia and the Department of Environmental Protection, Australia; 1994 
9. National Biodiversity Strategy and Action Plan Myanmar. Habitat and Ecosystem Diversity. National Environmental Conservation Committee. 2001.

10. Sutherland JW, Newton L, Green RE. Bird Ecology and Conservation. Oxford University Press; 2004.

11. Smythies BE. The birds of Burma. Natural History Publications (Boneo); 2001.

12. Robson. A field guide to the birds of South-East Asia, Concise Edition. London; Bloombury Publishers (UK) Ltd; 2016.

13. Avibase, Bird checklists of the world, Myanmar. 2017.
14. Scott A. The cultural economy of cities. International Journal of Urban and Regional Research. 1997;21(2):323-339.

15. BirdLife International. The BirdLife checklist of the birds of the world, with conservation status and taxonomic sources. Version 5; 2012.

16. Tordoff AW, Appleton T, Eames JC, et al. The historical and current status of Pink-headed Duck Rhodonessa caryophyllacea in Myanmar. Bird Conservation International. 2008;18(1):38-52.

17. Lebbin DJ, Parr MJ, Fenwick GH. The American Birds Conservancy Guide to Bird conservation. The University of Chicago Press; 2010. 